\title{
CAMBRIDGE JURNALS
}

\section{European Business Organization Law Review (EBOR)}

Marketed and distributed for T.M.C. Asser Press

\section{Editor}

Rainer Kulms, Max Planck Institute, Hamburg, Germany

The European Business Organization Law Review $(E B O R)$ is a leading European publication addressing all legal aspects of business organization. The journal is a platform for articles, case-notes and book reviews to stimulate scholarly debate and to reflect the speed of how developments in the field translate into substantive law. Relying on scholars, business people, lawyers, economists and other disciplines, and with an international editorial board, the journal looks at the whole range of problems relevant to business activities and the corresponding national, European Community and international legal rules.

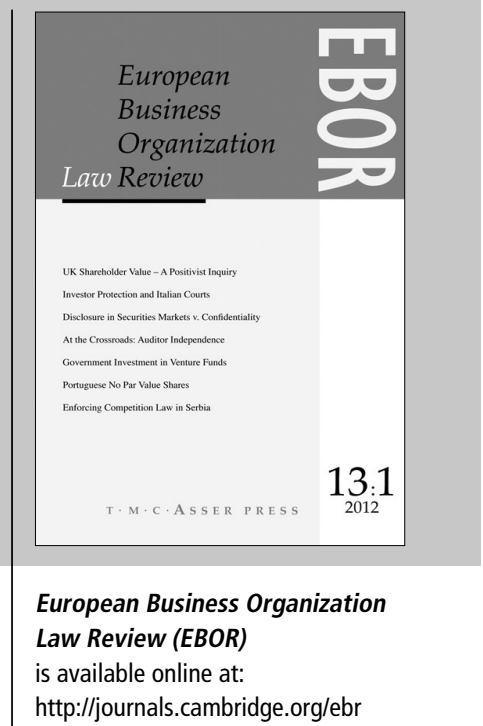

To subscribe contact Customer Services

\section{in Cambridge:}

Phone +44 (0)1223326070

Fax $+44(0) 1223325150$

Email journals@cambridge.org

in New York:

Phone (845) 3537500

Fax (845) 3534141

Email

subscriptions_newyork@cambridge.org

\section{Free email alerts}

Keep up-to-date with new material - sign up at

journals.cambridge.org/ebr-alerts 


\section{CAMBRIDGE JURNALS}

\section{British}

Journal of Political

\section{Science}

\section{Editors}

Shaun Bowler, University of California, Riverside, USA

Kristian Skrede Gleditsch, University of Essex, UK

Robert E. Goodin, Australian National University, Australia and University of Essex, UK

Robert Johns, University of Essex, UK

René Lindstädt, University of Essex, UK

Hugh Ward, University of Essex, UK

The British Journal of Political Science (BJPO/S) is a broadly based journal aiming to cover developments across a wide range of countries and specialisms. Contributions are drawn from all fields of political science (including political theory, political behaviour, public policy and international relations), and articles from scholars in related disciplines (sociology, social psychology, economics and philosophy) appear frequently. With a reputation established over 40 years of publication, the BJPo/S is widely recognised as one of the premier journals in its field.
British Journal of Political Science is available online at: http://journals.cambridge.org/bjpols

To subscribe contact

\section{Customer Services}

\section{in Cambridge:}

Phone +44 (0)1223 326070

Fax +44 (0)1223 325150

Email journals@cambridge.org

\section{in New York:}

Phone (845) 3537500

Fax (845) 3534141

Email

subscriptions_newyork@cambridge.org

\section{Free email alerts}

Keep up-to-date with new material - sign up at

journals.cambridge.org/jps-alerts 


\section{JOURNAL OF INSTITUTIONAL ECONOMICS}

\section{SUBMISSION}

All manuscripts must be submitted online via the website:

http://mc.manuscriptcentral.com/joie

Detailed instructions for submitting your manuscript online can be found at the submission website by clicking on the 'Instructions and Forms' link in the top right of the screen; and then clicking on the 'Author Submission Instructions' icon on the following page.

The Editor will acknowledge receipt of the manuscript, provide it with a manuscript reference number and assign it to reviewers. The reference number of the manuscript should be quoted in all correspondence with JOIE Office and Publisher.

\section{ARTICLE}

There must be no indication of the personal identity or institution of any author of the article within the article itself, or in the 'properties' of the electronic file. Normally, articles (including footnotes and references) must be no longer than 9,000 words. In special cases, such as an extended review or survey article, this limit may be extended to 12,000 words. A declaration of the total word count (including footnotes and references) must accompany or be within the article.

Papers with some formal content will be considered if it is fully explained for a general readership, the mathematics is consigned as much as possible to appendices, the assumptions have sufficient grounding in reality, and the paper enhances our understanding of past, present, or feasible socio-economic institutions. JOIE is not interested in the advancement of formal or econometric technique for their own sake.

The front page of the electronic file of the article should include the following information: the title; an abstract of the article of up to 150 words; the Journal of Economic Literature classification codes for the article (consisting of a single letter followed by two numeric digits, see www.aeaweb.org/journal/ jel_class_system.html); and up to six key words or short phrases.

Footnotes should be kept to a minimum and the Harvard referencing system should be used.

Submission of a paper will be held to imply that it contains original unpublished work and is not being submitted for publication elsewhere.

The JOIE Editors will preliminarily assess all papers. A paper will be rejected at this first stage if it does not comply with the above guidelines, is evidently of insufficient academic quality or interest, or lies outside the scope of the journal. If a paper passes this preliminarily assessment, then it will be sent out to referees. The five Editors will make the final decision, taking account of the referee's reports.

If the article is accepted, the author will be ask to comply with the format and house style of JOIE, as exhibited in issues of the journal from June 2005.
AIMS

"Institutions are the stuff of social and economic life. Many influential organizations, including the World Bank, have recognized the importance of institutions for economic development. The Nobel Prize has been awarded to Ronald Coase, Douglass North, Gunnar Myrdal and Simon Kuznets for their pioneering work in institutional economics."

"The Journal of Institutional Economics is devoted to the study of the nature, role and evolution of institutions in the economy, including firms, states, markets, money, households and other vital institutions and organizations. It welcomes contributions by all schools of thought that can contribute to our understanding of the features, development and functions of real world economic institutions and organizations."

"Many economists regard the principle of scarcity as central. However, this principle is not generally extended to scarcity of human cognitive or calculative abilities: these are often assumed to be unlimited. Furthermore, social institutions are often assumed as given, freely available, or producible at insignificant cost. In contrast, institutional economics regards institutions as costly to produce, and sees human beings as reliant on social customs and institutions in order to make decisions. Institutional economics addresses the issues of learning and cognition, and their relationship with institutional structures, cultures, routines, and habits."

"The Journal of Institutional Economics is dedicated to the development of cutting edge research within this broad conception of institutional economics. It encompasses research in both the 'original' and 'new' traditions of institutional economics, from Gustav Schmoller, Thorstein Veblen, John R. Commons, Wesley Mitchell and Gunnar Myrdal, to Ronald Coase, Oliver Williamson, Douglass North and many others."

"The Journal of Institutional Economics promotes theoretical and empirical research that enhances our understanding of the nature, origin, role and evolution of socioeconomic institutions. Ideas from many disciplines, such as anthropology, biology, geography, history, politics, psychology, philosophy, social theory and sociology, as well as economics itself, are important for this endeavor."

"Papers with some formal content will be considered if it is fully explained for a general readership, the mathematics is consigned as much as possible to appendices, the assumptions have sufficient grounding in reality, and the paper enhances our understanding of past, present, or feasible socio-economic institutions. The Journal of Institutional Economics is not interested in the advancement of formal or econometric technique for their own sake."

\section{RELEVANT LINKS}

http://journals.cambridge.org/JOI www.millennium-economics.com

\section{SUBSCRIPTIONS}

The Journal of Institutional Economics (ISSN I744-I374) from 2011 JOIE will appear in Mar, Jun, Sep and Dec each year

The 2015 subscription price (excluding VAT) of a volume, which includes print and electronic access, is $£_{303} .00$ (Us $\$ 506.00$ in
USA, Canada and Mexico); £35.00 (Us \$58.00) for individuals, which includes print only, ordering direct from the publishers and certifying that the journal is for their personal use. The electronic-only price available to institutional subscribers is $£ 250.00$ (us \$4I8.0o in USA, Canada and Mexico). Single parts are $£ 84.00$ net (US \$I4I.OO in USA, Canada and Mexico) plus postage. EU subscribers (outside the UK) who are not registered for VAT should add VAT at their country's rate. VAT registered members should provide their VAT registration number. Japanese prices for institutions (including ASP delivery) are available from Kinokuniya Company Ltd, P.o. Box 55, Chitose, Tokyo I56, Japan.

Orders, which must be accompanied by payment, may be sent to a bookseller, subscription agent or direct to the publisher: Cambridge University Press, Journals Fulfillment Department, UPH, Shaftesbury Road, Cambridge CB2 8BS, UK. or in the usa, Canada and Mexico: Cambridge University Press, Journals Fulfillment Department, Ioo Brook Hill Drive, West Nyack, New York I0994-2I33. Periodicals postage paid at New York, NY and at additional offices.

COPYING

This journal is registered with the Copyright Clearance Center, 222 Rosewood Drive, Danvers, MA OI923, USA. Organizations in the USA who are also registered with the c.c.C. may, therefore copy material (beyond the limits permitted by, sections 107 and 108 of us Copyright law) subject to payment to the C.C.C of the per copy fee of \$I2.00. This consent does not extend to multiple copying for promotional or commercial purposes. Code 0307-8833/15. ISI Tear Sheet Service, 350I Market Street, Philadelphia, PA I9IO4, USA, is authorized to supply single copies of separate articles for private use only. Organizations authorized by the Copyright Licensing Agency may also copy, material subject to the usual conditions. For all other use, permission should be sought from Cambridge or from the American Branch of Cambridge University Press.

(C) Millennium Economics Ltd 20I5

ISSN I744-I374

Printed in the United Kingdom by BELL AND BAIN LTD

This journal issue has been printed on FSC-certified paper and cover board. FSC is an independent, non-governmental, not-forprofit organization established to promote the responsible management of the world's forests. Please see www.fsc.org for information. 


\section{JOURNAL OF INSTITUTIONAL ECONOMICS}

VOL 11 ' NO 1 $\cdot$ MARCH 2015

\section{CONTENTS}

1 Economics for a creative world

Roger Koppl, Stuart Kauffman, Teppo Felin and Giuseppe Longo

33 Creative economics for a creative world: a comment David Colander

39 Next steps toward an economics for a creative world: a comment John Foster

47 Economics for a creative world: some agreements and some criticism Pavel Pelikan

55 Causality and regularity in a 'creative world' Ulrich Witt

61 Economics for a creative world: a response to comments Roger Koppl, Stuart Kauffman, Teppo Felin and Giuseppe Longo

69 History as a laboratory to better understand the formation of institutions Bas Van Bavel

93 Coasean method: lessons from the farm Douglas W. Allen

111 The dictator effect: how long years in office affect economic development Kostadis J . Papaioannou and Jan Luiten Van Zanden

141 Inequality and culture in a cross-section of countries Andreas P. Kyriacou and Francisco José López Velásquez

167 The political economy of special economic zones Lotta Moberg

191 Historical analysis of institutions and organizations: the case of the Brazilian electricity sector Guilherme Signorini, R. Brent Ross and H. Christopher Peterson 